\title{
ELIMINATION OF INDUSTRIAL TEXTILE DYE BY ELECTROCOAGULATION USING IRON ELECTRODES
}

\author{
JORGE VIDAL, CAROLINA ESPINOZA, NICOLE CONTRERAS, RICARDO SALAZAR*
}

Laboratorio de Electroquímica del Medio Ambiente, LEQMA. Departamento de Química de los Materiales, Facultad de Química y Biología, Universidad de Santiago de Chile, USACH, Casilla 40, Correo 33, Santiago, Chile

\begin{abstract}
Electrocoagulation is a promising technique for the treatment of wastewater like the produced by the textile industry, which generates large volumes of water containing dyes. Thus, synthetic samples of the textile dye acid black 194 (AB194, CI 22910) were treated by this method using iron anodes at two different initial $\mathrm{pH}$ values. Tafel studies in the presence and absence of the dye were performed.

The complete removal of AB194 from 1.0 L of solution in a static cell was achieved, at short electrolysis times, applying low-density currents at two different initial $\mathrm{pH}$ values.

In addition, the operating costs by mass consumed anode, per cubic meter electocoagulated and per TOC unit, were assessed to help determine the most efficient conditions, considering a future application of the method in the industry.
\end{abstract}

Keywords: Acid Black 194 Dye; Iron Anode; Electrocoagulation; Wastewater; Chemical Oxygen Demand.

\section{INTRODUCTION}

Several methods are available for the removal of dyes from wastewater, such as adsorption ${ }^{1,2}$ (e.g. activated carbons, silica, biosorbents), membrane separation $^{3,4}$ (e.g., microfiltration ultrafiltration, nanofiltration), precipitation ${ }^{5}$, photo degradation $^{6-7}$, biodegradation ${ }^{8,9}$, coagulation and electrocoagulation ${ }^{10-15}$. The electrocoagulation method (EC) is a simple and efficient electrochemical technique where an applied potential between two electrodes produces metal ions from the electrode material (sacrifice anode), forming coagulants in the wastewater, which eliminate the inorganic and/or organic matters dissolved or in suspension in the wastewater. Usually, the material used as an anode in EC corresponds to iron ${ }^{16-17,18}$ or aluminum ${ }^{19-20,21}$, whose oxidation equations are shown in (1) and (2):

$\mathrm{Fe} \rightarrow \mathrm{Fe}^{2+}+2 \mathrm{e}^{-}\left(\mathrm{E}^{0}=-0.44 \mathrm{~V} \text { vs. } \mathrm{SHE}\right)^{22}$

$\mathrm{Al} \rightarrow \mathrm{Al}^{3+}+3 \mathrm{e}^{-}\left(\mathrm{E}^{0}=1.66 \mathrm{~V} \text { vs. SHE }\right)^{22}$

These metal ions of iron or aluminum anodes produce insoluble $\mathrm{Fe}(\mathrm{OH})_{3}$ and $\mathrm{Al}(\mathrm{OH})_{3}$ flocs, which are $\mathrm{pH}$ dependent ${ }^{23-25}$, which remove dissolved inorganic and organic compounds by surface complexation or electrostatic attraction.

Moreover, at the cathode, hydrogen is simultaneously generated due to reduced water (3). The hydrogen gas would also help to float the flocculated particles out of the water, favoring the separation of the contaminants ${ }^{26}$.

$$
3 \mathrm{H}_{2} \mathrm{O}_{(\mathrm{l})}+3 \mathrm{e}^{-} \rightarrow 3 / 2 \mathrm{H}_{2(\mathrm{~g})}+3 \mathrm{OH}^{-}{ }_{(\mathrm{aq})}
$$

EC differs from conventional chemical coagulation in that the addition of coagulants to the system is not required, thus the possibility of secondary pollution by the addition of chemical substances at high concentrations is avoided. In addition, there is also a more rapid and effective separation of organic compounds from the solution compared to coagulation and the operating costs are lower compared to conventional techniques ${ }^{27}$. In the literature, we have witnessed the application of this method to real cases such as catering water for the removal of colloidal matter; oil in water emulsions from restaurants; and urban, agro-industrial and textile industry wastewater with a high content of organic pollutants and suspended solids ${ }^{28,29}$.

Iron electrodes present two mechanisms that explain the in situ formation of two possible coagulants $\left(\mathrm{Fe}(\mathrm{OH})_{2}\right.$ and $\left.\mathrm{Fe}(\mathrm{OH})_{3}\right)$.

The formation of $\mathrm{Fe}(\mathrm{OH})_{2}(5)$ occurs when $\mathrm{Fe}^{2+}$ produced according to equation (1) reacts with $\mathrm{OH}^{-}$produced according to (3), generating an increase in $\mathrm{pH}$ during electrolysis.

$$
\mathrm{Fe}^{2+}{ }_{(\text {ac })}+2 \mathrm{OH}_{(\text {(ac) }}^{-} \rightarrow \mathrm{Fe}(\mathrm{OH})_{2(\mathrm{~s})}
$$

$\mathrm{Fe}(\mathrm{OH})_{2}$ is insoluble and precipitates at $\mathrm{pH}>5.5$, also it remains at equilibrium with $\mathrm{Fe}^{2+}$ until $\mathrm{pH}$ 9.5. Moreover, $\mathrm{Fe}(\mathrm{OH})_{2}$ is in equilibrium with monomeric species such as $\mathrm{Fe}(\mathrm{OH})^{+}, \mathrm{Fe}(\mathrm{OH})_{2}$ and $\mathrm{Fe}(\mathrm{OH})_{3}{ }^{-}$at high $\mathrm{pH}$ values.

In the presence of $\mathrm{O}_{2}$, dissolved $\mathrm{Fe}^{2+}$ ions are oxidized and give rise to the formation of the insoluble specie $\mathrm{Fe}(\mathrm{OH})_{3}$ according to equation (6):

$$
4 \mathrm{Fe}^{2+}{ }_{(\mathrm{ac})}+10 \mathrm{H}_{2} \mathrm{O}_{(\mathrm{l})}+\mathrm{O}_{2(\mathrm{~g})} \rightarrow 4 \mathrm{Fe}(\mathrm{OH})_{3(\mathrm{~s})}+8 \mathrm{H}^{+}{ }_{(\text {ac) }}
$$

Besides, the protons produced in equation (6) can be directly reduced to $\mathrm{H}_{2}$ gas at the cathode (7):

$$
8 \mathrm{H}^{+}{ }_{\text {(ac) }}+8 \mathrm{e}^{-} \rightarrow 4 \mathrm{H}_{2(\mathrm{~g})}
$$

It is known that the species of $\mathrm{Fe}(\mathrm{OH})_{3}$ predominate at high concentrations in a wide range of $\mathrm{pH}>1.0$, while $\mathrm{Fe}(\mathrm{OH})$ is found in high concentrations in the lower range, $\mathrm{pH}>5.5^{30}$. Furthermore, these species can be found in equilibrium with mono or polymeric species.

Acid black $194^{31}$ (AB194, CI 22910) is one of the textile dyes reported by the Chilean textile industry. The fact of its attachment to the fibers being through hydrophobic interactions instead of electrostatic ion-ion interactions between dye anions and protonated amino groups of fibers contribute to its strong affinity dye-substrate. AB194 is considered an azo dye, because its structure has a double bond $\mathrm{N}=\mathrm{N}$ (Table 1) acting as chromophore in the molecule. Also, this dye has a central metal ion corresponding to $\mathrm{Cr}$ (III) which gives it the property to cause chronic toxicity, it is mutagenic and carcinogenic; therefore, it should be removed from the water after the dyeing process.

This paper reports the EC treatment of $1.0 \mathrm{~L}$ of AB194 solutions carried out at constant current using a monopolar electrolytic cell with an iron cathode and anode, since this metal is one of the most abundant metals in the Earth's crust. Polarization curves were performed with and without AB194 in the solution. Applied current density, initial $\mathrm{pH}$, and dye concentration on the rates of decolorization, chemical oxygen demand (COD) decay, and total organic carbon (TOC) abatement were studied to establish optimum conditions for the process.

\section{EXPERIMENTAL METHODS}

\subsection{Materials}

Acid Black 194 (AB194) (chromium (III) complexes: trisodium, bis[(E)-7nitro-3-oxido-4-((2-oxidonaphthalen-1-yl)diazenyl)naphthalene-1-sulfonate] chromate(3-), 38\% purity, Table 1) was supplied by Textil Monarch S.A. (Santiago, Chile) and was used as received. Solutions of sodium chloride were used as supporting electrolyte prepared with distilled water with a conductivity of $<6 \mathrm{mS}$ at $25^{\circ} \mathrm{C}$, and their $\mathrm{pH}$ was adjusted with $\mathrm{HCl}$. All reagents were analytical grade from Merck ${ }^{\circledR}$.

2.2. Electrochemical system

A volume of $1.0 \mathrm{~L}$ of solution containing $\mathrm{AB} 194$ with $3.0 \mathrm{~g} \mathrm{~L}^{-1}$ of $\mathrm{NaCl}$ as supporting electrolyte at $25 \pm 1.0^{\circ} \mathrm{C}$ was treated by Electrocoagulation in a static cell. Two initial $\mathrm{pH}$ values were used: 4.0 and 8.5 . These values were selected from the limits established in the Chilean Standards DS609 ${ }^{32}$. Textile wastewater let out after a production process contains a large amount of dyes and other chemicals such as additives and salts. Sodium chloride is the most common chemical found in textile wastewater. The use of $\mathrm{NaCl}$ was around 
$15-90 \mathrm{Kg} / 100 \mathrm{Kg}$ of cloth. $3.0 \mathrm{~g} \mathrm{~L}^{-1}$ of $\mathrm{NaCl}$ is in the limits of Chilean Standards DS609.

During the experiments, the solution was stirred vigorously with a magnetic stirrer. The electrodes were $99.9 \%$ purity iron plates, purchased from Maquimetal Ltda. The total effective electrode area was $128 \mathrm{~cm}^{2}$ and the interelectrode gap was $2 \mathrm{~cm}$. Prior to the electrolysis, the electrodes (anode and cathode) were prepared by first cleaning them with acetone, then with $500 \mathrm{~mL}$ of $1.3 \mathrm{M} \mathrm{HCl}$ solution, and finally with distilled water to remove surface grease and impurities present on the electrode's surface. At the end of the electrolysis, the electrodes were rinsed thoroughly with distilled water to remove all solid residues from the surface and then they were dried and weighed. All the electrocoagulation experiments were performed at constant current using an EHQ Power model PS3010 power supply, which also displayed the cell voltage.

\subsection{Apparatus and analytical procedures}

The solution $\mathrm{pH}$ was measured with a pH/ORP model HI 8424. The decolorization of AB194 solutions was monitored from the absorbance (A) decrease at the maximum visible wavelength $(\lambda \max )$ of $574 \mathrm{~nm}$, measured from the spectra recorded on an Agilent model 8453 spectrophotometer. The elimination of dye AB194 was monitored from the decay of their TOC determined on a Select Elementar model Vario TOC; from decay of their COD, which was determined on a digester HANNA model HI 839800 and a photometer HANNA model HI 83099; and also from the decay of turbidity determined on a portable turbidimeter HANNA model HI 98703. All samples were filtered through membranes with micropores of $0.45 \mu \mathrm{m}$ JET Biofil to remove particles precipitated before each analysis.

For a better analysis of the viability of the EC treatment, the energy consumption per unit TOC mass $\left(\mathrm{EC}_{\mathrm{ToC}}\right)$, per unit volume $(\mathrm{EC})$ and per electrode mass $\left(\mathrm{EC}_{\text {anode }}\right)$ were calculated from $\mathrm{Eq}(8),(9)$ and (10) respectively:

$$
\begin{gathered}
E C_{T O C}\left(k W h K^{-1} \text { TOC }\right) \frac{1000 E I t}{(\Delta T O C)_{\text {exp }} V_{s}} \\
E C\left(k W h \mathrm{~m}^{-3}\right)=\left(\frac{E_{c e l} l t}{V_{s}}\right) \\
E C_{\text {anode }}\left[k W h\left(K_{\text {metal }}\right)^{-1}\right]=\frac{E I t}{\Delta m_{\text {anode }}}
\end{gathered}
$$

Where $\mathrm{E}_{\text {cell }}$ is the average cell voltage $(\mathrm{V})$, $\mathrm{I}$ is the applied current (A), is the electrolysistime (h), $\mathrm{V}$ is the volume of the treated solution $(\mathrm{L}), \Delta \mathrm{m}$ corresponds to the mass of the anode $(\mathrm{g})$ and $(\triangle \mathrm{TOC})_{\exp }$ to the variation of the

\begin{tabular}{|c|c|}
\hline Commercial name & $\begin{array}{l}\text { Acid Black } 194 \text { (CAS Number: } \\
\text { 61931-02-0) }\end{array}$ \\
\hline Chemical structure & \\
\hline IUPAC name & $\begin{array}{l}\mathrm{Cr}(\mathrm{III}) \text { complexes Trisodium, } \\
\text { bi[(E)-7-nitro-3-oxido-4-[(2- } \\
\text { oxidonaphthalen-1-yl) diazenyl] } \\
\text { naphtha-lene-1-sulfonate] } \\
\text { chromate (3) }\end{array}$ \\
\hline Color index (C.I) & 22910 \\
\hline Molecular formula & $\mathrm{C}_{40} \mathrm{H}_{24} \mathrm{~N}_{6} \mathrm{O}_{14} \mathrm{~S}_{2} \mathrm{Cr}_{2} \mathrm{Na}$ \\
\hline Molecular weight & $758.7 \mathrm{~g} / \mathrm{mol}$ \\
\hline
\end{tabular}
experimental values of TOC.

Table 1. Chemical structure and characteristics of dye.

\section{RESULTS AND DISCUSSION}

1.1 Effect of current density on the removal of AB194

Current density is an important parameter that controls the rate of the electrochemical and chemical reactions that occur in a solution. As the literature reports, the production rate of a coagulant at the anode and growth of bubbles of $\mathrm{H}_{2}$ at the cathode depend on the applied current density ${ }^{28,33}$. Hence, both phenomena favor the growth of the flocs and AB194 dye elimination from solutions. The EC of dye was performed using different current densities $(0.5$, 2.5, 5.0 and $10.0 \mathrm{~mA} \mathrm{~cm}^{-2}$ ). Figure 1a and $\mathrm{b}$ shows the absorbance decays (At $\mathrm{A}_{0}$ ) of dye $\left(\lambda_{\max }=574 \mathrm{~nm}\right)$ at different times. It may be seen a discolorization of the solution dependent on the applied current density at both initial $\mathrm{pHs}$ studied. At pH 4.0 (Fig. 1a) a complete discolorization of the solution within 30 minutes of electrolysis is reached using the higher current density $(10.0 \mathrm{~mA}$ $\mathrm{cm}^{-2}$ ), while with $5.0 \mathrm{~mA} \mathrm{~cm}^{-2}$, a total discolorization is achieved at 60 minutes. When applying current density of 2.5 and $0.5 \mathrm{~mA} \mathrm{~cm}^{-2}$, the total removal of the dye in 60 minutes of electrolysis is not achieved. When the initial $\mathrm{pH}$ is 8.5 (Fig 1b), there is also a dependence on the discoloration of the solution with respect to the applied current density, since at 30 minutes of electrolysis, total color removal is achieved using $10.0 \mathrm{~mA} \mathrm{~cm}$. With $5.0 \mathrm{~mA} \mathrm{~cm}$, the solution is completely decolorized at 40 minutes. However, applying low current densities $\left(2.5\right.$ and $\left.0.5 \mathrm{~mA} \mathrm{~cm}^{-2}\right)$ at $\mathrm{pH} 8.5$, it is not possible to achieve the complete removal of the dye before 60 minutes of electrolysis. According to these analyzes, the most effective current density was $5.0 \mathrm{~mA} \mathrm{~cm}^{-2}$ applied to solutions of initial $\mathrm{pH} 8.5$, because after 40 minutes they reached about $90 \%$ discolorization solution.

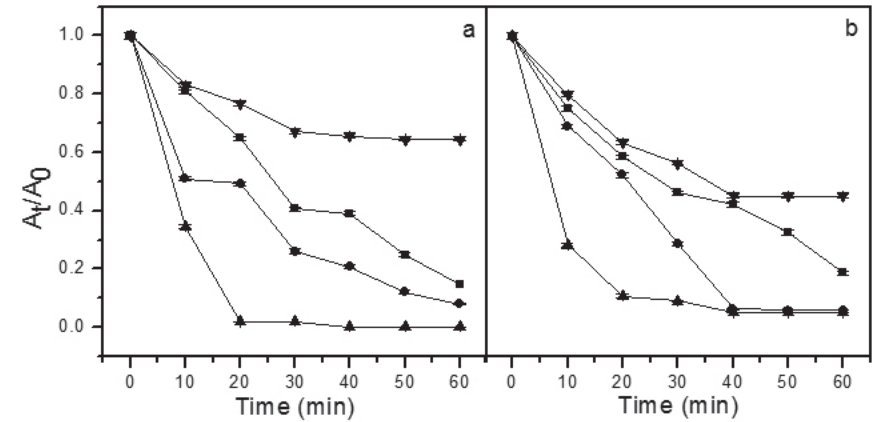

Figure 1. Evolution of UV-Vis spectrums of AB194 dye during the course of electrolysis at initial $\mathrm{pH}$ (a) 4.0 and (b) 8.5. Experimental conditions: dye concentration of $336 \mathrm{mg} \mathrm{L}^{-1}, 3000 \mathrm{mg} \mathrm{L}^{-1}$ of $\mathrm{NaCl}$ : ( $\left.\mathbf{\nabla}\right) 0.5 \mathrm{~mA} \mathrm{~cm}^{-2}$, (- 2.5 $\mathrm{mA} \mathrm{cm}{ }^{-2},(\bullet) 5 \mathrm{~mA} \mathrm{~cm}^{-2},(\Delta) 10 \mathrm{~mA} \mathrm{~cm}^{-2}$.

Polarization curves using iron electrodes as working electrodes in the absence and presence of $\mathrm{AB} 194$ dye in the supporting electrolyte of $\mathrm{NaCl}$, at initial $\mathrm{pH}$ of 4.0 and 8.5 , were carried out (Figure 2). The Tafel extrapolation method was used to obtain the potentials and corrosion currents. In the absence of dye, at $\mathrm{pH} 4.0$, the $\mathrm{E}_{\text {corr }}=-600 \mathrm{mV}$ whereas at $\mathrm{pH} 8.5 \mathrm{E}_{\text {corr }}=-470 \mathrm{mV}$. , that is, at $\mathrm{pH} 4.0$, iron corrosion is favored in $130 \mathrm{mV}$ in comparison when the $\mathrm{pH}$ of the solution is 8.5. Due to the metal passivation that occurred between -780 and $-560 \mathrm{mV}$, at both $\mathrm{pH}$, the corrosion current increased in $0.19 \mathrm{~mA}$ when the $\mathrm{pH}$ of the solution was 8.5 . When the dye is added to the solution, iron oxidation is favored at both $\mathrm{pH}$, with similar corrosion currents.

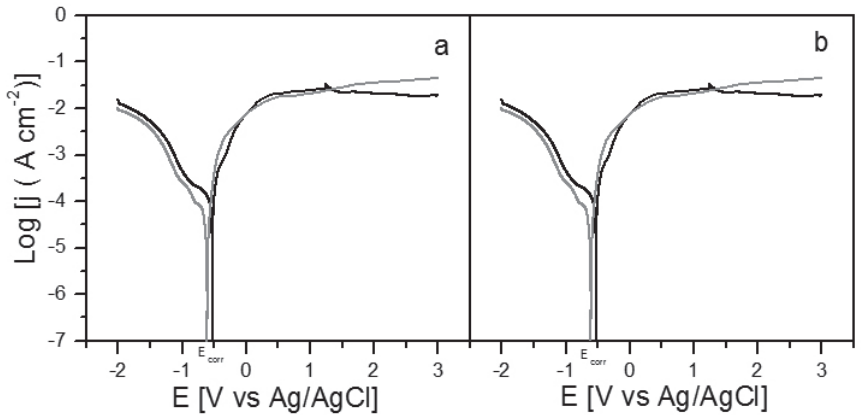

Figure 2. Potentiodynamic polarization curve by Tafel extrapolation method in the absence ( - ) and presence ( - ) of dye at initial $\mathrm{pH}$ (a) 4.0 an (b) 8.5. Operating Conditions: $25^{\circ} \mathrm{C}, 3000 \mathrm{mg} \mathrm{L}^{-1} \mathrm{NaCl}$; anode: pure $\mathrm{Fe}\left(1 \mathrm{~cm}^{2}\right)$; cathode: Pt wire; reference electrode: saturated $\mathrm{Ag} / \mathrm{AgCl}$; scan speed: $0.5 \mathrm{mV}$ $\mathrm{s}^{-1}$. 
Table 2. Potential and current corrosion surface in the absence and presence of AB194 dye.

\begin{tabular}{|c|c|c|c|}
\hline dye & Initial $\mathrm{pH}$ & E corrosion $(\mathrm{mV})$ & i corrosion $(\mathrm{mA})$ \\
\hline absence & 4.0 & -600 & 0.33 \\
\hline absence & 8.5 & -470 & 0.52 \\
\hline presence & 4.0 & -510 & 0.48 \\
\hline presence & 8.5 & -440 & 0.52 \\
\hline
\end{tabular}

On the other hand, the $\mathrm{pH}$ variation of the solution was studied over time electrolysis by applying different current densities at different initial $\mathrm{pH}$. Figure 3a shows that, starting with an initial $\mathrm{pH} 4.0$, increased $\mathrm{pH}$ is observed for all existing applied current densities during the first hour of electrolysis. At times greater than 30 minutes, the $\mathrm{pH}$ of the solution reaches a substantially constant value until the end of the experiment. It is also observed that the $\mathrm{pH}$ of the solution depends directly on the current applied, where the higher the applied current density, the higher the $\mathrm{pH}$ value reached in the solution.

A different behavior was observed in the electrolysis carried out with an initial $\mathrm{pH}$ of 8.5 using the same range of current densities (Figure 3b). When a current density of $0.5 \mathrm{~mA} \mathrm{~cm}^{-2}$ is applied, a decrease in $\mathrm{pH}$, which reaches a value close to 6.0 , is observed during the course of the electrolysis, while with current densities between 2.5 to $10.0 \mathrm{~mA} \mathrm{~cm}{ }^{-2}$, there is an increase in the $\mathrm{pH}$ of the solution during the first 20 minutes of electrolysis, which then remains constant until the end of the experiment. Moreover, current densities of 5.0 and $10.0 \mathrm{~mA} \mathrm{~cm}{ }^{-2}$ achieve the same $\mathrm{pH}$ value $(10-10.2)$, implying that the $\mathrm{pH}$ of the solution becomes independent of the current applied under these experimental conditions, as it reached a current limit. These results explain de behavior observed in Figure 1, whereas higher removal of the dye is obtained at initial $\mathrm{pH} 8.5$, but the corrosion potential obtained at $\mathrm{pH} 4.0$ is lower than at $\mathrm{pH}$ 8.5 (Figure 2). It is known that, at $\mathrm{pH}>6.0$, the concentration of $\mathrm{Fe}(\mathrm{OH})_{3}$, from the Fe sacrificial anodes, is 1000 times greater than acidic $\mathrm{pH}^{16-18}$.

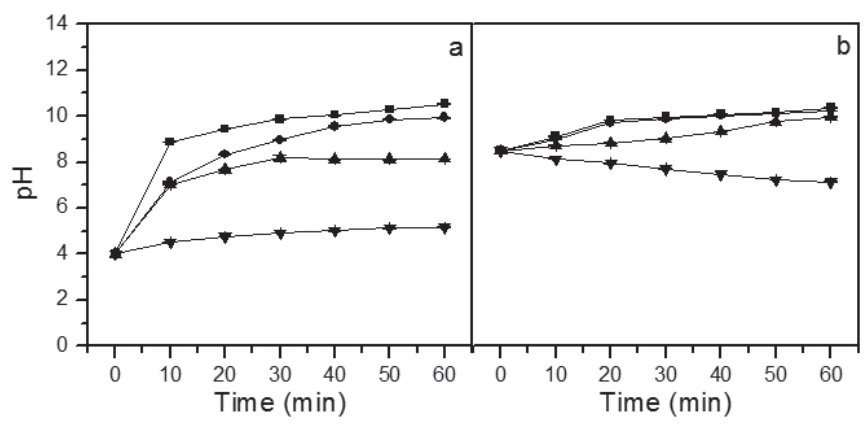

Figure 3. Effect of initial $\mathrm{pH}$ applying different current densities in dye absence, $3000 \mathrm{mg} \mathrm{L}^{-1} \mathrm{NaCl}$, initial pH of (a) 4.0 (b) $8.5:$ ( $\left.\mathbf{\nabla}\right) 0.5 \mathrm{~mA} \mathrm{~cm}^{-2}$, (-) $2.5 \mathrm{~mA} \mathrm{~cm}^{-2},(\bullet) 5 \mathrm{~mA} \mathrm{~cm}^{-2},(\boldsymbol{\Delta}) 10 \mathrm{~mA} \mathrm{~cm}-2$

In Figure $3 \mathrm{~b}$ as above mentioned, a decrease in initial $\mathrm{pH}$ was observed at a current density of $0.5 \mathrm{~mA} \mathrm{~cm}^{-2}$, because most of the hydroxyl ions that are generated at the cathode participate in the formation of the coagulant $\mathrm{Fe}(\mathrm{OH})_{2}$ by reaction (5), thus decreasing the $\mathrm{OH}^{-}$concentration in the solution. The above explained is directly related to the current applied, since by increasing the current density greater potential difference is generated, which is independent of the initial $\mathrm{pH}$, allowing the electrogeneration of a greater amount of $\mathrm{Fe}^{2+}$ ions at the anode and hydroxide ions at the cathode, producing several reactions in solution (reactions 5 and 6 ).

In the same direction, the concentration of iron species generated in solution is strongly related to the $\mathrm{pH}$ and the applied current, since electrochemical rate generation of species is lower at lower currents. This causes a low $\mathrm{pH}$ value and a lower potential difference that may not be sufficient to generate a large amount of iron species to form the flocs and remove the dye from the solution.

Iron dissolution from the anode was evaluated $\left(\mathrm{m}_{\text {exp }}\right)$ during electrolysis. The referred amount of released iron anode was measured and compared with the theoretically calculated amount that is expected to be dissolved, using Faraday's law. Figure $4 \mathrm{a}$ and $4 \mathrm{~b}$, from initial $\mathrm{pH} 4.0$ to $\mathrm{pH} 8.5$, respectively, show a comparison between theoretical and experimental iron concentration under different specific experimental electric charges $\left(\mathrm{A} \mathrm{h} \mathrm{L}^{-1}\right)$ using current densities of $0.5 \mathrm{~mA} \mathrm{~cm}-2$ to $10.0 \mathrm{~mA} \mathrm{~cm}^{-2}$, for 60 minutes of electrolysis and in the absence of dye. The theoretical concentration of iron (in $\mathrm{g} \mathrm{L}^{-1}$ ) was calculated using Faraday's law, assuming completely used electrical energy provided only to oxidize $\mathrm{Fe}$ to $\mathrm{Fe}^{2+}$.

According to Faraday's law, the electric charge "q" is calculated from the following equation:

$$
\mathrm{q}=2 \times \mathrm{F} \times \frac{\mathrm{m}_{\mathrm{Fe}}}{\mathrm{M}_{\mathrm{Fe}}} \rightarrow \mathrm{m}_{\mathrm{Fe}}=\frac{\mathrm{q} \times \mathrm{M}_{\mathrm{Fe}}}{2 \times \mathrm{F}} \rightarrow[\mathrm{Fe}]=\frac{\mathrm{q} \times \mathrm{M}_{\mathrm{Fe}}}{2 \times \mathrm{F} \times \mathrm{v}}
$$

During electrolysis, the current density is constant; therefore the electric charge (q) and the specific electric charge (Q) are defined, respectively, by the following equations:

$$
q(A s)=I x t y Q\left(A h L^{-1}\right)=\frac{I x t}{3600 \times v}
$$

Next, the theoretical amount of dissolved iron is given by the following equation:

$[\mathrm{Fe}]\left(\mathrm{g} \mathrm{L}^{-1}\right)=\frac{\mathrm{I} \times \mathrm{MM}_{\mathrm{Fe}}}{2 \times \mathrm{Fxv}}=\frac{3600 \times \mathrm{Q} \times \mathrm{M}_{\mathrm{Fe}}}{2 \times \mathrm{F}}=0.366 \times \mathrm{Q}\left(\mathrm{A} \mathrm{h} \mathrm{L}^{-1}\right)$

Where $[\mathrm{Fe}]$ is the amount of iron produced (in $\left.\mathrm{g} \mathrm{L}^{-1}\right) ; I$ is the intensity of the current (A), $t$ is the electrolysis time (s), $M$ is molecular mass ( $\mathrm{M}=55,845$ g mol-1); $F$ is the Faraday constant $\left(96487 \mathrm{C} \mathrm{mol}^{-1}\right), v$ is the volume of the solution $(1 \mathrm{~L})$, and $Q$ is the specific electric load $\left(\mathrm{A} \mathrm{h} \mathrm{L}^{-1}\right)$.

As seen in both Figures $4 \mathrm{a}$ and $4 \mathrm{~b}$, the theoretical and experimental concentration of iron increases according to the amount of specific electrical charge that joined the system every 60 minutes. However, at both initial pH, the measurement of iron concentration correlates well with the theoretical concentration, as experimentally obtained values are very similar to the theoretical ones.

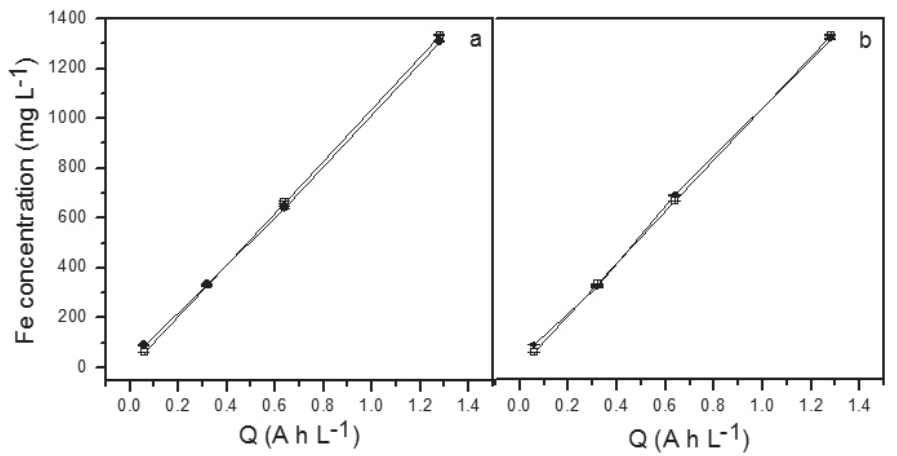

Figure 4. Theoretical (घ) and experimental () concentration of iron evolved from the anode under different specific electrical loads. Experimental conditions: $3000 \mathrm{mg} \mathrm{L}^{-1}$ of NaCl, 60 minutes of electrolysis time. Initial $\mathrm{pH}$ (a) 4.0, (b) 8.5

TOC decay was measured after 60 minutes of electrolysis, as shown in Table 3. These results show that higher TOC decay values are obtained by increasing the applied current density, and that up to $75 \%$ of TOC removal applying current densities are higher than $5.0 \mathrm{~mA} \mathrm{~cm}^{-2}$. These results confirm those obtained in Figure 3, where for both $\mathrm{pH}$, at lower applied current densities, a lower percentage of TOC removal is obtained and therefore there is lower color removal from the solution.

The total cost of the process according to the anode mass released by the current applied to the system (Table 4), per cubic meter of volume treated (Table 5) and per unit of TOC consumed (Table 6), were calculated. According to this data, it is observed that as the current density increases, so does the energy consumed in each of the evaluated processes, which leads to increased operating costs. Furthermore, in dye electrocoagulation, applying $5.0 \mathrm{~mA}$ $\mathrm{cm}^{-2}$, kilogram of mass of iron electrode detached (Table 4) costs less than US $\$ 1$, regardless the $\mathrm{pH}$ of the solution. Similar costs are obtained under these experimental conditions, for example, the cost of the process to EC $1 \mathrm{~m}^{3}$ of solution (Table 5) corresponds to a low cost if projected at an industrial level. Finally, it is possible to observe, under these same conditions, that the cost of the process per kilogram of dye removed by TOC (Table 6) is close to US $\$ 6$. 
Table 3. TOC decay during electrocoagulation of $336 \mathrm{mg} \mathrm{L}^{-1}$ of NA194 dye applying different current densities in $3000 \mathrm{mg} \mathrm{L}^{-1}$ of $\mathrm{NaCl}_{\mathrm{with}}$ initial pH of 4.0 and $8.5, \mathrm{j}=0.5 \mathrm{~mA} \mathrm{~cm}^{-2}, 2.5 \mathrm{~mA} \mathrm{~cm}^{-2}, 5.0 \mathrm{~mA} \mathrm{~cm}^{-2}, 10.0 \mathrm{~mA} \mathrm{~cm}^{-2}$.

\begin{tabular}{|c|c|c|c|c|}
\hline $\begin{array}{c}\text { Current Density } \\
\left(\mathrm{mA} \mathrm{cm}^{-2}\right)\end{array}$ & initial $\mathrm{pH}$ & Initial TOC $\left(\mathrm{mg} \mathrm{L}^{-1}\right)$ & Final TOC $\left(\mathrm{mg} \mathrm{L}^{-1}\right)$ & \% TOC decay \\
\hline 0.5 & 4.0 & $95.70 \pm 0.070$ & $86.55 \pm 0.777$ & 9 \\
\hline 0.5 & 8.5 & $95.75 \pm 0.141$ & $76.95 \pm 0.070$ & 20 \\
\hline 2.5 & 4.0 & $95.65 \pm 0.212$ & $34.50 \pm 0.707$ & 65 \\
\hline 2.5 & 8.5 & $95.75 \pm 0.070$ & $56.95 \pm 1.343$ & 40 \\
\hline 5.0 & 4.0 & $95.65 \pm 0.212$ & $22.75 \pm 1.060$ & 75 \\
\hline 5.0 & 8.5 & $95.70 \pm 0.141$ & $20.90 \pm 1.272$ & 77 \\
\hline 10.0 & 4.0 & $95.60 \pm 0.288$ & $12.60 \pm 0.848$ & 86 \\
\hline 10.0 & 8.5 & $95.85 \pm 0.070$ & $11.80 \pm 1.131$ & 87 \\
\hline
\end{tabular}

Table 4. Operating cost by mass consumed electrode applying different current densities.

\begin{tabular}{|c|c|c|c|}
\hline $\begin{array}{c}\text { Current Density } \\
\left(\mathrm{mA} \mathrm{cm}^{-2}\right)\end{array}$ & $\begin{array}{c}\text { Initial } \\
\mathrm{pH}\end{array}$ & $\begin{array}{c}\text { Energy consumed } \\
\text { per mass of electrode } \\
\left(\mathrm{kWhKg}^{-1}\right)\end{array}$ & $\begin{array}{c}\text { Operating costs per } \\
\text { mass of electrode } \\
\left(\mathrm{US} \mathrm{K}^{-1}\right)\end{array}$ \\
\hline 0.5 & 4.0 & 0.960 & 0.18 \\
\hline 0.5 & 8.5 & 1.056 & 0.20 \\
\hline 2.5 & 4.0 & 2.036 & 0.40 \\
\hline 2.5 & 8.5 & 2.521 & 0.48 \\
\hline 5.0 & 4.0 & 3.534 & 0.67 \\
\hline 5.0 & 8.5 & 2.961 & 0.56 \\
\hline 10.0 & 4.0 & 5.967 & 1.13 \\
\hline 10.0 & 8.5 & 6.256 & 1.18 \\
\hline
\end{tabular}

Table 5. Operating costs per cubic meter removed applying different current densities at 60 minutes of electrolysis.

\begin{tabular}{|c|c|c|c|}
\hline $\begin{array}{l}\text { Current density } \\
\left.\qquad(\mathrm{mA} \mathrm{cm})^{-2}\right)\end{array}$ & Initial $\mathrm{pH}$ & $\begin{array}{l}\text { Energy consumed } \\
\text { by } \mathrm{m}^{3}\left(\mathrm{kWhm}^{-3}\right)\end{array}$ & $\begin{array}{l}\text { Operating cost by } \\
\mathrm{m}^{3}\left(\mathrm{US} \$ \mathrm{~m}^{-3}\right)\end{array}$ \\
\hline 0.5 & 4.0 & 0.060 & 0.01 \\
\hline 0.5 & 8.5 & 0.066 & 0.01 \\
\hline 2.5 & 4.0 & 0.672 & 0.13 \\
\hline 2.5 & 8.5 & 0.832 & 0.16 \\
\hline 5.0 & 4.0 & 2.368 & 0.50 \\
\hline 5.0 & 8.5 & 1.984 & 0.38 \\
\hline 10.0 & 4.0 & 7.936 & 1.50 \\
\hline 10.0 & 8.5 & 8.320 & 1.58 \\
\hline
\end{tabular}

Table 6. Operating cost per unit of TOC removed applying different current density at 60 minutes of electrolysis.

\begin{tabular}{|c|c|c|c|c|c|}
\hline Current density $\left(\mathrm{mA} \mathrm{cm}^{-2}\right)$ & $\begin{array}{c}\text { Initial } \\
\mathrm{pH}\end{array}$ & Initial TOC $\left(\mathrm{mg} \mathrm{L}^{-1}\right)$ & Final TOC $\left(\mathrm{mg} \mathrm{L}^{-1}\right)$ & $\begin{array}{c}\text { Energy consumed by TOC } \\
\left(\mathrm{kWhKg}^{-1}\right)\end{array}$ & $\begin{array}{c}\text { Operating cost (US\$ } \\
\text { Kg-1 TOC) }\end{array}$ \\
\hline 0.5 & 4.0 & $95.58 \pm 0.403$ & $55.31 \pm 0.483$ & 1.479 & 0.28 \\
\hline 0.5 & 8.5 & $95.63 \pm 0.332$ & $60.06 \pm 0.750$ & 1.843 & 0.35 \\
\hline 2.5 & 4.0 & $95.53 \pm 0.473$ & $30.47 \pm 0.373$ & 10.275 & 1.94 \\
\hline 2.5 & 8.5 & $95.73 \pm 0.190$ & $46.46 \pm 1.034$ & 16.839 & 3.19 \\
\hline 5.0 & 4.0 & $95.88 \pm 0.021$ & $16.16 \pm 0.593$ & 29.707 & 5.62 \\
\hline 5.0 & 8.5 & $95.48 \pm 0.544$ & $21.30 \pm 0.921$ & 26.606 & 5.04 \\
\hline 10.0 & 4.0 & $95.58 \pm 0.403$ & $5.65 \pm 1.172$ & 87.968 & 16.65 \\
\hline 10.0 & 8.5 & $95.53 \pm 0.473$ & $9.51 \pm 0.344$ & 96.341 & 18.24 \\
\hline
\end{tabular}


Thus, optimum removal of acid black 194 dye, under our experimental conditions, is obtained by working at an initial $\mathrm{pH}$ of 8.5 applying a current density of $5.0 \mathrm{~mA} \mathrm{~cm}^{-2}$, in the presence of $3000 \mathrm{mg} \mathrm{L}^{-1}$ of supporting electrolyte $(\mathrm{NaCl})$ for a dye concentration of $336 \mathrm{mg} \mathrm{L}^{-1}$, which corresponds to $100 \mathrm{mg}$ $\mathrm{L}^{-1}$ of TOC (Figure 5). Therefore, the chemical oxygen demand, TOC decay and turbidity during 60 minutes of electrolysis, were finally evaluated as elimination patterns under the experimental conditions stated above. Seventy four percent of COD elimination, $76 \%$ of TOC removal and $83 \%$ of removal turbidity are obtained. Also, during the first 20 minutes of electrolysis, there is an increase in turbidity due to the iron monomeric species formed during electrocoagulation, which has a yellow coloration acquired by the ion $\mathrm{Fe}^{3+}$ and also exists in fine particles in the $\mathrm{Fe}(\mathrm{OH})_{3}$ species, that is difficult to dissolve. It is important to note that the solution was completely decolorized within 30 minutes of electrolysis and that reached values of 0 UA.

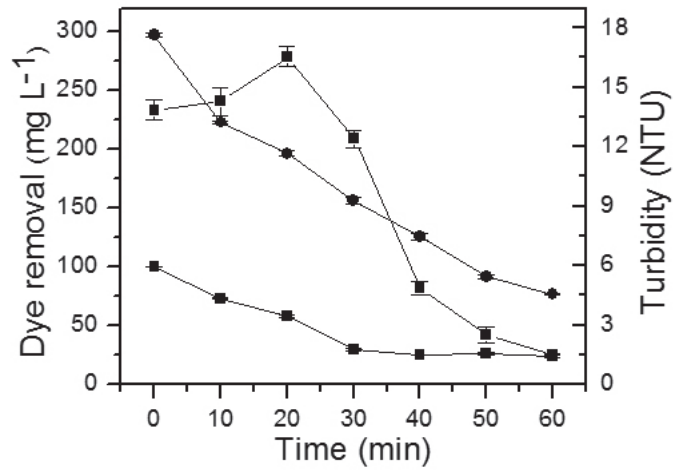

Figure 5. Evaluation of $(\bullet) \mathrm{COD}$ and $(\mathbf{\square})$ TOC decay, ( $\mathbf{\Delta})$ turbidity elimination at optimum experimental conditions: initial $\mathrm{pH}$ of 8.5 , current density of $5.0 \mathrm{~mA} \mathrm{~cm}{ }^{-2}$, dye concentration of $336 \mathrm{mg} \mathrm{L}^{-1}$ in $3000 \mathrm{mg} \mathrm{L}^{-1}$ of supporting electrolyte $\mathrm{NaCl}$.

\section{CONCLUSIONS}

Using a static cell, it was possible to carry out the electrocoagulation of the textile dye acid black 194. The elimination of the dye using iron electrodes was effective by applying high current densities $\left(5.0\right.$ and $\left.10.0 \mathrm{~mA} \mathrm{~cm}{ }^{-2}\right)$, reaching a total discolorization in less than 60 minutes and a total organic carbon decay over $75 \%$. Subsequently, it was possible to establish that the best experimental conditions of $\mathrm{pH}$ and current density are 8.5 and $5 \mathrm{~mA} \mathrm{~cm} \mathrm{~cm}^{-2}$, respectively. Parameters such as turbidity, conductivity and absorbance, reaching values of $2.53 \mathrm{NTU}, 5.78 \mathrm{mS} \mathrm{cm}^{-1}$ and $0 \mathrm{UA}$, respectively, were also assessed. Finally, in terms of operational costs, using EC for AB194 is an important alternative for treatment in the textile industry, because this method does not involve significant economic costs.

\section{REFERENCES}

[1].- Zeng S, Duan S, Tang R, Li L, Liu C, Sun D. Magnetically separable $\mathrm{Ni}_{0} \mathrm{Fe}_{24} \mathrm{O}$ nanoparticles as an effective adsorbent for dye removal: Synthesis and study on the kinetic and thermodynamic behaviors for dye adsorption. Chemical Engineering Journal 258: 218-228 (2014).

[2].- Fernandez M, Nunell G, Bonelli P, Cukierman A. Activated carbon developed from orange peels: Batch and dynamic competitive adsorption of basic dyes. Industrial Crops and Products 62: 437-445, (2014).

[3].- Liu M, Chen Q, Lu K, Huang W, Lü Z, Zhou C, Yu S, Gao C. High efficient removal of dyes from aqueous solution through nanofiltration using diethanolamine-modified polyamide thin-film composite membrane. Separation and Purification Technology 173: 135-143 (2017).

[4].- Liu C Mao H, Zheng J, Zhang J. Tight ultrafiltration membrane: Preparation and characterization of thermally resistant carboxylated cardo poly (arylene ether ketone)s (PAEK- COOH) tight ultrafiltration membrane for dye removal ). Journal of Membrane Science 530: 1-10 (2017).

[5].- Xu Zhu M, Lee L, Wang H, Wang Z. Removal of an anionic dye by adsorption/precipitation processes using alkaline white mud. Journal of Hazardous Materials 149: 735-741 (2007).

[6].- Fahimirad B, Asghari A, Rajabi M. Photo-degradation of basic green 1 and basic red 46 dyes in their binary solution by La2O3A12O3nanocomposite using first-order derivative spectra and experimental design methodology. Spectrochimica Acta Part A: Molecular and Biomolecular Spectroscopy 179: 58-65 (2017).

[7].- Debnatha S, Ballava N, Nyoni H, Maity A, Pillaya K. Optimization and mechanism elucidation of the catalytic photo-degradation of the dyes Eosin Yellow (EY) and Naphthol blue black (NBB) by a polyaniline-coated titanium dioxide nanocomposite. Applied Catalysis B: Environmental 163: 330-342 (2015).

[8].- Kurade M, Waghmode T, Patil S, Jeon B, Govindwar S. Monitoring the gradual biodegradation of dyes in a simulated textile effluent and development of a novel triple layered fixed bed reactor using a bacterium-yeast consortium. Chemical Engineering Journal 307: 10261036 (2017).

[9].- Almeida E, Corso C. Comparative study of toxicity of azo dye Procion Red MX-5B following biosorption and biodegradation treatments with the fungi Aspergillus niger and Aspergillus terreus. Chemosphere 112: 317-322 (2014).

[10].- Mbackéa M, Kanea C, Dialloa N, Diopa C, Chauvetb F, Comtatb M, Tzedakis T. Electrocoagulation process applied on pollutants treatmentexperimental optimization and fundamental investigation of the crystal violet dye removal. Journal of Environmental Chemical Engineering 4: 4001-4011 (2016).

[11].- Phalakornkule C, Polgumhang S, Tongdaung W, Karakat B, Nuyut T. Electrocoagulation of blue reactive, red disperse and mixed dyes, and application in treating textile effluent. Journal of Environmental Management 91: 918-926 (2010).

[12].- Aoudja S, Khelifab A, Drouichea N, Hecinia M, Hamitouche H. Electrocoagulation process applied to wastewater containing dyes from textile industry. Chemical Engineering and Processing 49: 1176-1182 (2010).

[13].- Zodi S, Merzouk B, Potier O, Lapicque F, Leclerc J. Direct red 81 dye removal by a continuous flow electrocoagulation/flotation reactor Separation and Purification Technology 108: 215-222 (2013).

[14].- Chafi M, Gourich B, Essadki A, Vial C, Fabregat A. Comparison of electrocoagulation using iron and aluminium electrodes with chemical coagulation for the removal of a highly soluble acid dye. Desalination 281: 285-292 (2011).

[15].- Merzouk B, Gourich B, Madani K, Vial Ch, Sekki A. Removal of a disperse red dye from synthetic wastewater by chemical coagulation and continuous electrocoagulation. A comparative study. Desalination 272: 246-253 (2011).

[16].- Mahmoud M, Farah J, Farrag T. Enhanced removal of Methylene Blue by electrocoagulation using iron electrodes. Egyptian Journal of Petroleum 22: 211-216 (2013).

[17].- Akyol A , Can O, Demirbas E, Kobya M. A comparative study of electrocoagulation and electro-Fenton for treatment of wastewater from liquid organic fertilizer plant. Separation and Purification Technology 112: 11-19 (2013).

[18].- Sahu O, Chaudhari P. Electrochemical treatment of sugar industry wastewater: $\mathrm{COD}$ and color removal. Journal of Electroanalytical Chemistry 739: 122-129 (2015).

[19].- Millar G, Lin J, Arshad A, Couperthwaite S. Evaluation of electrocoagulation for the pre-treatment of coalseam water. Journal of Water Process Engineering 4: 166-178 (2014).

[20].- Benhadji A, Ahmed M, Maachi R. Electrocoagulation and effect of cathode materials on the removal of pollutants from tannery wastewater of Rouilba. Desalination 277: 128-134 (2011).

[21].- Ricordel C, Djelal H. Treatment of landfill leachate with high proportion of refractory materials by electrocoagulation: System performances and sludge settling characteristics. Journal of Environmental Chemical Engineering 2: 1551-1557 (2014).

[22].- Raymond Chang. 9st ed. México D.F. McGraw-Hill Interamericana. Ch. 19 , p. 828 (2007)

[23].- David C, Arivazhagan M, Tuvakara F . Decolorization of distillery spent wash effluent by electro oxidation (EC and $\mathrm{EF}$ ) and Fenton processes: A comparative study. Ecotoxicology and Environmental Safety 121: 142-148 (2015).

[24].- Song P, Yang Z, Zeng G, Yang X, Xu H, Wang L, Xu R, Xiong W, Ahmad K. Electrocoagulation treatment of arsenic in wastewaters: A comprehensive review. Chemical Engineering Journal 317: 707-725 (2017)

[25].- Fajardo A, Rodrigues R, Martins R, Castro L, Quinta-Ferreira R. 
Phenolic wastewaters treatment by electrocoagulation process using $\mathrm{Zn}$ anode. Chemical Engineering Journal 275: 331-341 (2015).

[26].- Hakizimana J, Gourich B, Chafi M, Stiriba Y, Vial C, Drogui P, Naja J. Electrocoagulation process in water treatment: A review of electrocoagulation modeling approaches. Desalination 404: 1-21 (2017).

[27].- Kobya M, Oncel M, Demirbas E, Şık E, Akyol A, Ince M. The application of electrocoagulation process for treatment of the red mud dam wastewater from Bayer's process. Journal of Environmental Chemical Engineering 2: 2211-2220 (2014).

[28].- Vidal J, Villegas L, Peralta-Hernández J.M, Salazar R. Removal of Acid Black 194 dye from water by electrocoagulation with aluminum anode. Journal of Environmental Science and Health, Part A 51: 289-296 (2016).

[29].- Zaleschi L, Secula M, Teodosiu C, Stan C, Cretescu I. Removal of Rhodamine $6 \mathrm{G}$ from Aqueous Effluents by Electrocoagulation in a Batch
Reactor: Assessment of Operational Parameters and Process Mechanism. Water, Air \& Soil Pollution 225: 101-2114 (2014).

[30].- Martínez-Huitle C, Brillas E. Decontamination of wastewaters containing synthetic organic dyes by electrochemical methods: A general review. Applied Catalysis B: Environmental 87: 105-145 (2009).

[31].- Sebastiano R, Contiello N, Senatore S, Righetti P, Citterio A. Analysis of commercial Acid Black 194 and related dyes by micellar electrokinetic chromatography. Dyes and Pigments 94: 258-265, (2014).

[32].- Emission standard for the regulation of contaminants associated with liquid waste discharges to marine and continental surface waters (DO 07.03.2001), Executive Power, Ministry General Secretariat of the Presidency, Chile

[33].- Treatment of highly concentrated tannery wastewater using electrocoagulation: Influence of the quality of aluminium used for the electrode, Journal of Hazardous Materials 319: 69-77, (2016). 